\title{
PENUMBUHAN BUDI PEKERTI BERBASIS LINGKUNGAN MELALUI MODEL KONSTRUKTIVISME DALAM PEMBELAJARAN MATEMATIKA
}

\author{
Muh. Fakhrudin Suryana \\ Guru SMP Negeri 3 Teras Boyolali \\ fakhrudin_s3mpd@yahoo.co.id
}

\begin{abstract}
This research is motivated by the demands offactually growing conditions in characterbased environment through a constructivist approach to provide alternative solutions in building and increasing quality of Indonesian human resources. The purpose of the research objective want to describe the motivation, cultivation of characterbased environment, and learning achievement. The subject research of class VII A State of Junior High School Three Teras Boyolali second semester of the 2015/2016 academic year as many as 27 students. Methods of data collection using observation, questionnaire, documentation, and testing. Analysis of data using a critical and comparative analysis. Indicators of success using criteria limit minimal amounted to 75 , and $100 \%$ completeness class. Research procedure uses cycles. The results of research and discussion is known that: the data obtained from pre cycle until the second cycle, obtained advances growth of the manners of learners in mathematics, in pre cycle average of 74 and the first cycle an average of 78 and the second cycle by an average of 81 . from this data, it seems clear that an increase in the average value of pre cycle to the first cycle of four digits (5.4\%), from the first cycle to the second cycle an increase of 3 digits (3.7\%), from pre cycle to the second cycle an increase of 7 digits (9.5\%). The highest value growth of character (character education) on pre cycle by 83, the first cycle of 86, and the third cycle of 89 There is an increase of pre cycle the highest value to the first cycle of 3 digits (3.6\%), from the first cycle to the second cycle occurs an increase of 3 digits (3.5\%), and the second cycle of pasiklus to an increase of 6 digits (7.2\%). Data from pre cycle lowest value of 64, the first cycle of 70, and the second cycle of 74. There was an increase in the lowest value of pre cycle to the first cycle of six digits $(9.4 \%)$, from the first cycle to the second cycle an increase of 6 digits ( $8.6 \%)$, and the second cycle of pasiklus to an increase of 12 digits (18.8\%). Percentage of learning achievement obtained in pre cycle by $41 \%$ and in the first cycle by $78 \%$ and the second cycle of $100 \%$. Growth pre cycle character from the first cycle to an increase in class achievement by $37 \%$, from the first cycle to the second cycle there is an increase of $22 \%$, and from pre cycle to the second cycle there is an increase of 59\%. This means that the cultivation of character (character education) learners in mathematics from pre cycle until the second cycle there is a significant rise. Thus, it can be affirmed that the approach can optimize the consrtructivism cultivating of character.
\end{abstract}

Keywords: cultivation of character, constructivism 


\section{PENDAHULUAN}

Pentingnya pendidikan bagi kehidupan manusia adalah untuk mencapai harkat dan martabat manusia yang sesungguhnya, karena di dalamnya memuat motivasi berprestasi (mencapai keinginan yang terbaik), membentuk karakter yang kuat (nilai, kebenaran, sikap, perilaku yang melekat diri), dan prestasi terbaik (produk/hasil, keterampilan, kecakapan, dan sejenisnya), yang dapat diimplementasikan dalam kehidupan nyata sehari-hari dan memberikan manfaat yang luas (manusia dan alam). Penumbuhan budi pekerti atau yang sejenis disebut dengan istilah pendidikan berkarakter tertuang dalam Undang-Undang Nomor : 20 Tahun 2003 Bab II Pasal 3 yaitu : "Pendidikan nasional berfungsi mengembangkan kemampuan dan membentuk watak serta peradaban bangsa yang bermartabat, bertujuan untuk berkembangnya potensi peserta didik agar menjadi manusia yang beriman dan bertaqwa kepada Tuhan Yang Maha Esa, berakhlak mulia, sehat, berilmu, sehat, kreatif, mandiri, dan menjadi warga negara yang demokratis serta bertanggung jawab"

Pendidikan karakter (penumbuhan budi pekerti) adalah gerakan nasional untuk menciptakan sekolah yang membina generasi muda yang beretika, bertanggung jawab, dan peduli melalui pemodelan dan mengajarkan karakter baik dengan penekanan pada nilai universal yang kita setujui bersama (Jihad, dkk, 2010: 60). Budi pekerti peserta didik sangat penting dan dijadikan titik tolak dalam penguasaan ilmu pengetahuan dan teknologi, sebagai dasar membangun pribadi yang memiliki mental spritual, kesehatan rohaniah, dan jasmaniah yang utuh.

Prinsip konstruktivisme, seharusnya peserta didik membangun pengetahuan peserta didik sendiri, baik secara personal maupun sosial. Pengetahuan tidak dapat dipindahkan dari guru ke peserta didik, kecuali melalui keaktifan peserta didik sendiri untuk menalar. Peserta didik aktif mengkonstruksi terus-menerus sehingga selalu terjadi perubahan konsep menuju ke lebih rinci, lengkap, serta sesuai dengan konsep ilmiah. Guru bertindak membantu menyediakan sarana dan situasi agar proses konstruksi peserta didik berjalan Guru memegang peran yang sangat penting dalam proses belajar mengajar. Guru berkewajiban menyediakan lingkungan belajar yang kondusif agar peserta didik merasa senang tidak bosan sehingga menambah interaksidan keikutsertaan peserta didik dalam belajar (Setyarini, 2007: 4).

Berdasarkan latar belakang, pembatasan, dan identifikasi masalah tersebut di atas, dapat dirumuskan masalah berikut ini: Apakah melalui model konstruktivisme dalam pembelajaran matematika dapat mengoptimalkan penumbuhan budi pekerti berbasis lingkungan? Selanjutnya, tujuan yang hendak dicapai, yaitu tujuan umum, ingin mengetahui tentang kegiatan penumbuhan budi pekerti peserta didik di SMP Negeri 3 Teras Boyolali, sedangkan tujuan khusus, yaitu ingin mengetahui penerapan model konsrtruktivisme terhadap penumbuhan budi pekerti dalam pembelajaran, sekaligus dampaknya terhadap prestasi belajar matematika fokus pada materi himpunan.

Manfaat yang diharapkan dari penelitian, yaitu manfaat teoritis, antara lain: mendapatkan deskripsi teoritis tentang penumbuhan budi pekerti berbasis lingkungan melalui model konstruktivisme dalam pembelajaran, dengan penelitian tindakan kelas tentang penumbuhan budi pekerti berbasis lingkungan melalui model konstruktivisme dalam pembelajaran dapat dikembangkan penelitian sejenis berikutnya oleh peneliti yang lain. Sedangkan manfaat praktis, antara lain: bagi peserta didik, optimalisasi penumbuhan budi pekerti berbasis 
lingkungan melalui model konstruktivisme dalam pembelajaran lebih baik dan berpartisipasi aktif dalam khususnya mata pelajaran matematika materi himpunan, bagi guru Matematika SMP dapat dipergunakan sebagai deskripsi tentang pentingnya penumbuhan budi pekerti berbasis lingkungan melalui model konstruktivisme dan memperhatikan materi ajar yang sesuai dengan indikator khususnya materi himpunan yang berdampak positif terhadap optimalisasi prestasi belajar peserta didik, dan bagi sekolah SMP Negeri 3 Teras Boyolali untuk meningkatkan mutu kinerja guru baik dalam pembelajaran maupun pengembangan profesi serta prestasi belajar peserta didik.

Berdasarkan latar belakang masalah dan perumusan masalah dapat diajukan hipotesis tindakan, yaitu: melalui pendekatan konstruktivisme dalam pembelajaran matematika dapat mengoptimalkan penumbuhan budi pekerti berbasis lingkungan.

\section{METODE}

Penelitian tindakan kelas ini berlangsung selama dua bulan, dimulai tanggal 02 Januari sampai dengan 15 Maret 2016. Penelitin ini dilakukan di SMP Negeri 3 Teras Boyolali semester genap tahun pelajaran 2015/2016. Subjek penelitian adalah peserta didik VII A SMP Negeri 3 Teras Boyolali semester genap tahun pelajaran 2015/2016 sebanyak 27 peserta didik. Sumber data dalam penelitian ini adalah kolaborator, peserta didik, dan referensi dan atau sumber data tertulis lsejenis. Teknik pengumpulan data menggunakan angket motivasi, observasi selama dan setelah dilaksanakan pembelajaran, dokumentasi, dan tes tertulis. Validitas data, jika terbukti nyata ada peningkatan afektif, kognitif, dan psikomotor dalam pembelajaran, maka data yang digunakan adalah valid. Penelitian ini adalah penelitian tindakan kelas, jadi tidak perlu menggunakan analisis statistik untuk menguji validitas data.

Teknik analisis data dalam penelitian ini menggunakan analisis kritis dan analisis komparatif. Teknik analisis kritis melaksanakan kegiatan mengungkap kelemahan dan kelebihan tindakan dan hasil dalam proses pembelajaran berdasarkan kriteria. Hasil analisis kritis dijadikan dasar dalam penyusunan perencanaan tindakan tahap berikutnya. Analisis kritis mencakup hasil angket, observasi, dan tes. sedangkan analisis komparatif adalah membandingkan data antarsiklus, kondisi awal dengan siklus pertama, dan seterusnya. Hasil analisis komparatif untuk mengetahui keberhasilan maupun kegagalan dalam setiap siklusnya.

Tindakan dalam penelitian menggunakan model Kemmis dan Mc Taggart. Model ini menggunakan siklus sistem spiral, masing-masing siklus terdiri dari empat komponen, yaitu rencana, tindakan, observasi dan refleksi. Rencana (planning), tindakan apa yang akan dilakukan penelitian untuk memperbaiki, meningkatkan proses dan hasil belajar di kelas. Tindakan (acting), apa yang dilakukan oleh peneliti sebagai upaya memperbaiki dan meningkatkan kondisi pembelajaran yang ada sehingga kondisi yang diharapkan dapat tercapai. Pegamatan (Observing), peneliti mengamati hasil atau dampak dari tindakannya. Refleksi (reflecting), peneliti mengkaji melihat dan mempertimbangkan atas dampak dari tindakan dengan menggunakan berbagai kriteria. Dari hasil refleksi tersebut peneliti melakukan memodifikasi terhadap rencana tindakan berikutnya (Suwandi, 2009).

Penelitian ini menetapkan indikator kinerja dari prasiklus (kondisi awal) ke siklus berikutnya, bila sudah optimal atau ada peningkatan partisipasi aktif dan perubahan sikap, kterampilan, dan intelektual, maka tindakan dihentikan. Intinya ada peningkatan hasil belajar 
peserta didik lebih baik sesuai Kriteria Ketuntasan Minimal (KKM) sebesar 75 dan ketuntasan kelas $100 \%$. Prosedur penelitian ini menggunakan siklus.

\section{HASIL DAN PEMBAHASAN}

Pembelajaran berlangsung belum sesuai tujuan, mengingat peserta didik belum menunjukkan keterlibatannya secara aktif, kondusif, dan motivasinya belum optimal, karakter peserta didik yang belum terbina dengan baik, peran guru belum optimal, lingkungan sekolah yang belum kondusif, dan sebagainya. Suasana pembelajaran pada prasiklus atau sebelum ada tindakan mulai dari kesiapan guru dalam pembelajaran, kegiatan guru dalam mempersiapkan kelas untuk pembelajaran, persiapan kelas untuk pembelajaran, motivasi, penumbuhan budi pekerti (pendidikan karakter), dan prestasi belajar peserta didik belum optimal, artinya belum sesuai dengan batas minimal yang telah ditetapkan untuk seluruh peserta didik. Hasil observasi guru dalam pembelajaran mulai dari menyampaikan tujuan pembelajaran, menyampaikan apersepsi, memberi motivasi, membimbing peserta didik, memberi kesempatan peserta didik untuk bertanya, memberi tugas, mengumpulkan tugas, memeriksa tugas, dan antusiasisme peserta didik mencapai klasifikasi penilaian rendah atau sebesar $60 \%$, dan belum optimal, karena peneliti menetapkan batas minimal 75\%, maka perlu ditindaklanjuti pada siklus I.

Hasil observasi guru dalam mempersiapkan kelas untuk pembelajaran mulai dari kelas yang bersih dan sehat, kelengkapan meja kursi guru dan peserta didik, presensi peserta didik, jadwal pembelajaran di kelas, dan piket peserta didik, suasana kelas untuk pembelajaran yang nyaman hingga pencap[aian tujuan pembelajaran mencapai klasifikasi penilaian rendah atau sebesar $60 \%$, dan belum optimal, karena peneliti menetapkan batas minimal 75\%, maka secara keseluruhan perlu ditindaklanjuti pada siklus I. Motivasi peserta didik dalam pembelajaran matematika, diperoleh nilai rata-rata 73 dalam klasifikasi penilaian cukup, karena sesuai dengan KKM sebesar 75. Secara terperinci motivasi peserta didik prasiklus (sebelum ada tindakan) dalam pembelajaran matematika klasifikasi tercapai dan atau terlampaui sebanyak 11 peserta didik (41\%), sisanya sebanyak 16 peserta didik (59\%) belum tercapai, karena peneliti menetapkan $100 \%$, maka perlu ditindaklanjuti siklus I

Penumbuhan budi pekerti (pendidikan karakter) peserta didik dalam pembelajaran matematika, diperoleh nilai rata-rata 74 dalam klasifikasi penilaian tinggi dan tercapai, karena KKM sebesar 75. Secara terperinci penumbuhan budi pekerti (pendidikan karakter) peserta didik prasiklus (sebelum ada tindakan) dalam pembelajaran matematika klasifikasi tercapai dan atau terlampaui sebanyak 11 peserta didik (41\%), sisanya sebanyak 16 peserta didik (59\%) belum tercapai, karena peneliti menetapkan 100\%, maka perlu ditindaklanjuti siklus I. Implementasi penumbuhan budi pekerti tahap prasiklus atau sebelum ada tindakan sebagaimana dilaksanakan seperti kebiasaan sehari-hari atau berlangsung secara konvensional seperti yang dilaksanakan oleh guru-guru lain. Guru datang lebih awal dan memandu kebersihan kelas, memantau kehadiran peserta didik dan cara berpakaian, apakah sudah rapi dan menggunakan seragam, kelengkapan atribut, memeriksa petugas piket peserta didik, dan sebagainya.

Prestasi belajar peserta didik dalam pembelajaran matematika, diperoleh nilai rata-rata 72 dalam klasifikasi penilaian tinggi, tetapi belum tercapai, karena KKM sebesar 75. Secara terperinci prestasi belajar peserta didik prasiklus (sebelum ada tindakan) dalam pembelajaran 
matematika klasifikasi penilaian belum tercapai ada 10 peserta didik (27\%), sebanyak 16 peserta didik (63\%) dalam klasifikasi penilaian tercapai dan atau terlampaui. Ketercapaian kelas sebanyak 16 peserta didik (63\%), karena peneliti menetapkan 100\%, maka perlu ditindaklanjuti siklus I.

Pembelajaran dibagi menjadi kelompok-kelompok kecil, setiap kelompok anggotanya 5 peserta didik. Kondisi pembelajaran sudah tampak antusias, komunikasi dan interaksi antarpeserta didik sudah efektif dan dalam bimbingan guru. Peserta didik bernai mengacungkan jari untuk menjawab pertanyaan guru. Kemudian, guru menunjuk seorang peserta didik putri untuk mendemonstraikan hasil kerja kelompoknya, kemudian guru mengamati hasil pekerjaan peserta didik tersebut, sambil mengkomunikasikan hasilnya pada peserta diskusi, apakah hasil pekerjaan tersebut sudah benar. Semua peserta didik mengamati, mencocokkan pekerjaannnya, ternyata sudah benar, meskipun ada beberapa yang belum benar. Hasil observasi guru dalam pembelajaran mulai dari menyampaikan tujuan pembelajaran dengan jelas hingga pencapaian yujuan pembelajaran mencapai klasifikasi penilaian cukup dan belum optimal sebesar $76 \%$, peneliti menetapkan 75 , masih perlu ditingkatkan atau dioptimalkan, antara lain menyampaikan materi pelajaran dengan jelas, Membimbing peserta didik secara rutin dan terstruktur, dan memberi kesempatan peserta didik bertanya, maka perlu ditindaklanjuti pada siklus II.

Hasil observasi guru dalam mempersiapkan kelas untuk pembelajaran mulai dari kelas yang bersih dan sehat, kelengkapan dan kerapihan meja kursi guru dan peserta didik hingga suasana kelas yang nyaman untuk pembelajaran belum optimal, tetapi secara keseluruhan sudah mencapai klasifikasi penilaian tinggi atau sebesar $74 \%$, dan sudah optimal, karena peneliti menetapkan batas minimal 75\%, namun masih perlu ditindaklanjuti atau dioptimalkan pada siklus II mulai kelas yang bersih, meja dan kursi peserta didik dan guru. Motivasi peserta didik dalam pembelajaran matematika, diperoleh nilai rata-rata 76 sudah terlampau namun masih ada 6 peserta didik (22\%) yang belum tercapai. namun belum mencapai 100\%, maka perlu ditindaklanjuti siklus II. Penumbuhan budi pekerti (pendidikan karakter) peserta didik dalam pembelajaran matematika, diperoleh nilai rata-rata 78 dalam klasifikasi terlampaui, namun masih ada 6 peserta didik (22\%) yang belum tercapai. Tercapai atau terlampaui, belum mencapai $100 \%$, maka perlu ditindak-lanjuti siklus II.

Guru melaksanakan penumbuhan budi pekerti (pendidikan karakter) sebagaimana yang terjadi pada tahap prasiklus, tetapi ada penekanan pada kegiatan peserta didik melakukan baris secara tertib dab disiplin sebelum memasuki kelas, dilanjutkan untuk berjabatan tangan dengan guru. Hal ini bertujuan untuk menciptakan suasana familiar, keakraban antara guru dan peserta didik, bermanfaat untuk media saling memaafkan antara guru dan peserta didik, dan setelah memasuki kelas, dilaksanakan berdo'a bersama dipandu, dan dipimpin ketua kelasnya. Setelah berdo'a, guru memberikan ucapan salam dan selamatkepada peserta didik, bahwa masih diberi kesempatan Tuhan untuk bertemu dan belajar bersama kembali dalam suasana sehat, bahagia, dan menikmati kebersamaan. Kemudian, guru memberikan pengantar arti pentingnya berdo'a bagi kita semua, di samping sebagai makhluk ciptaan Tuhan, manusia wajib mencari ilmu bagi masa depan kita. Guru juga menyampaikan arti pentingnya bekerjasama dengan teman atau orang lain, manusia juga merupakan makhluk sosial, membutuhkan orang lain dan saling menghargai, manusia hidup kalau bersama orang 
lain. Dalam siklus I ini, peserta didik mengalami perubahan perilaku yang lebih baik, peserta didik mulai peduli pada dirinya sendiri, peduli kepada orang lain, sekaligus peduli kepada Tuhan, sehingga dapat dicapai bahwa manusia sebagai makhluk pribadi, makhluk sosial, sekaligus makhluk ciptaan. Prestasi belajar peserta didik dalam pembelajaran matematika, diperoleh nilai rata-rata 76 dalam klasifikasi terlampaui, namun masih ada 6 peserta didik (22\%) yang belum tercapai, belum mencapai $100 \%$, maka perlu ditindaklanjuti siklus II.

Pembelajaran berlansung lebih kondusif, menarik, aktif, inovatif, kreatif, dan menyenangkan. Guru membuat kelompok-kelompok kecil, setiap kelompok anggotanya 5 peserta didik. Kompetisi peserta didik dalam menjawab pertanyaan guru lebih tinggi dibanding pada siklus I. Dalam hal ini, peserta didik lebih bersemangat,kompetisi untuk menguasai materi pembelajaran lebih tampak dan peserta didik berusaha menjawab dengan kemampuannya sendiri, meskipun jawaban tersebut merupakan hasildiskusi kecil dalam kelompoknya masing-masing, adanya kesungguhan partisipasi dan keingintahuan yang lebih tinggi di hadapan peserta didik semakin mendukung kegiatan pembelajaran lebih menarik. Dalam halini, guru menambah fasilitas pembelajaan berupa LCD, dan pelaksanaannya menggunakan moving class atau peserta didik selesai pembelajaran berpindah ke kelas lain.

Guru menunjuk seorang peserta didik untuk mendemonstrasikan hasil unjuk kerja kelompoknya, guru mengamati hasilnya, kemudian menanyakan kepada peserta diskusi lain untuk mencocokkan dengan hasil unjuk kerja kelompoknya masing-masing. Semua peserta diskusi menjawab hasilnya benar. Pembelajaran Siklus II tampak lebih hidup,kompetitif, kondusif, dan bergairah. Hasil observasi guru dalam pembelajaran mulai dari menyampaikan tujuan pembelajaran, apersepsi pembelajaran, memotivasi belajar peserta didik, menyampaikan materi pembelajaran hingga pencapaian tujuan pembelajaran mencapai klasifikasi penilaian sangat tinggi atau sebesar 94\%, dan sudah optimal, atau dengan kata lain pembelajaran berlangsung secara efektif, kondusif dan berhasil dengan meyakinkan.

Hasil observasi guru dalam mempersiapkan kelas untuk pembelajaran mulai dari kelas yang bersih dan sehat hingga pencapaian tujuan pembelajaran telah mencapai klasifikasi penilaian sangat tinggi atau sebesar 90\%, sudah optimal secara keseluruhan. Motivasi peserta didik dalam pembelajaran matematika, diperoleh nilai rata-rata 80 dalam klasifikasi penilaian sangat tinggi dan terlampaui. Secara terperinci motivasi peserta didik pada siklus II (setelah ada tindakan) dalam pembelajaran matematika klasifikasi penilaian tercapai dan atau terlampaui seluruhnya, sebanyak 27 peserta didik (100\%). Motivasi peserta didik dalam pembelajaran matematika yang terendah dengan nilai 75 dan tertinggi dengan nilai 89 , ratarata 80. Penumbuhan budi pekerti (pendidikan karakter) peserta didik dalam pembelajaran matematika, diperoleh nilai rata-rata 81 dalam klasifikasi terlampaui. Penumbuhan budi pekerti (pendidikan karakter) peserta didik dalam pembelajaran matematika yang terendah dengan nilai 76 terlampaui, dan tertinggi nilai 89, secara keseluruhan 30 peserta didik (100\%) tercapai

Implementasi penumbuhan budi pekerti (pendidikan karakter) pada tahapsiklus II atau tindakan kedua, guru melaksanakan kegiatan sebagaimana pada tahap siklus I, namun ada penekanan pada ibadah, sopan santun, disiplin, motivasi, kepedulian, dan kejujuran peserta didik dalam praktik kehidupan sehari-hari, misalnya ketika di rumah guru menanyakan 
apakah melaksanakan sholatlima waktu, membantu orang tua, melaksanakan belajar, dan ketika di sekolah, kehadiran peserta didik langsung dipantau guru, tidak terlambat, berpakaian rapi, melaksanakan piket kelas secara kompak dan bekerjasama dengan baik, melaksanakan baris dan antrian sebelum memasuki kelas, berdo'a bersama, memperhatikan penjelasan guru, mengerjakan tugas, dan sebagainya. Intinya, penumbuhan budi pekerti (pendidikan karakter) pada siklus II sudah menggambarkan peningkatan yang optimal, sehingga untuk pembelajaran berikutnya sudah terkondisi dengan baik dan lancar. Prestasi belajar peserta didik dalam pembelajaran matematika, diperoleh nilai rata-rata 82 dalam klasifikasi penilaian terlampaui. Prestasi belajar peserta didik dalam pembelajaran matematika yang terendah dengan nilai 76. terlampaui dan tertinggi dengan nilai 90, terlampaui, secara keseluruhan 30 peserta didik (100\%) tercapai.

Tahap prasiklus, peserta didik masih belum optimal, masih banyak kelemahan dan kekuranan, seperti karakteri peserta didik yang belum terbangun dengan baik berupa peserta didik masih kurang peduli pada kerjasama dalam piket kelas, masih ada sebagian peserta didik yang tidak memperhatikan penjelasan guru, dan tanggung jawab peserta didik ketika diberi pekerjaan rumah tidak diselesaikan, kebersihan kelas belum optimal, dan sebagainya.

Pada tahap siklus I atau setelah ada tindakan pertama mengalamiperubahan atau peningkatan yang lebih baik, peserta didik hadir tepat waktu, sebelum memasuki ruangan berbaris tertib dalam antrian bersama, memasuki kelas dan mengakhir pembelajaran berjabatan tangan dengan guru, perhatian peserta didik lebih fokus, pembelajaran tenang dan lebih nyaman, peserta didik mulai berani bertanya, kondisi diskusi lebih hidup dan kompetitif, meskipun masih ada peserta didik yang belum optimal.

Tahap siklus II atau tindakan kedua, sudah berlangsung secara optimal, baik implementasi penumbuhan budi pekerti (pendidikan karakter)nya maupun prestasi belajar peserta didik sudah mencapai optimal, karakter peserta didik mulai tampak meningkat lebih baik, peserta didik mulai peduli dalam segala kegiatan pembelajaran, tugas guru dilaksanakan dengan baik, diskusi berjalan lancar dan tumbuh kompetisi untuk menguasai materi serta unjuk kerja di depan kelas, motivasi optimal, penumbuhan budi pekerti (pendidikan karakter) berhasil dengan baik, dan prestasi belajar peserta didik mencapai 100\% tercapai, dengan nilai melampaui batas minimal.

Hasil temuan guru, mulai dari prasiklus atau prasiklus hingga siklus II terjadi kesinambungan yang tidak terputus, terbukti bahwa guru mampu melaksanakan kolaborasi dengan teman sejawat dalam mengimplementasikan penumbuhan budi pekerti (pendidikan karakter) dan pembelajaran, adanya peningkatan penumbuhan budi pekerti (pendidikan karakter) yang tumbuh dan meningkat di kalangan peserta didik dan prestasi belajar peserta didik, adanya kompetisi perubahan perilaku dan hasil belajar peserta didik berlangsung kondusif, di samping itu, peserta didik juga berhasil melaksanakan penumbuhan budi pekerti (pendidikan karakter) diluar kelas, baik di sekolah, keluarga, maupun di dalam lingkungan pergaulannya di masyarakat.

Hasil tindakan dari dari prasiklus hingga siklus II, diperoleh data kemajuan guru dalam pembelajaran, pada prasiklus sebesar 60\%, siklus I sebesar 70\% dan siklus II sebesar 94\%. Dari data ini menunjukkan bahwa ada kemajuan kesiapan guru dalam pembelajaran dari 
prasiklus ke siklus I sebesar 10\%, kemudian dari siklus I ke siklus II terjadi kenaikan sebesar $24 \%$ serta dari prasiklus ke siklus II sebesar 34\%. Dengan demikian, hasil obervasi guru dalam pembelajaran menunjukkan peningkatan yang signifikan.

Hasil tindakan dari prasiklus hingga siklus II, diperoleh data kemajuan guru dalam mempersiapkan kelas untuk pembelajaran, pada prasiklus sebesar $60 \%$, siklus I sebesar $74 \%$ dan siklus II sebesar 90\%. Dari data ini menunjukkan bahwa ada kemajuan persiapan kelas untuk pembelajaran dari prasiklus ke siklus I sebesar 14\%, kemudian dari siklus I ke siklus II terjadi kenaikan sebesar 16\% serta dari prasiklus ke siklus II sebesar 30\%. Dengan demikian, hasil obervasi guru dalam mempersiapkan kelas untuk pembelajaran menunjukkan peningkatan yang signifikan.

Hasil tindakan dari prasiklus hingga siklus II, diperoleh data kemajuan motivasi peserta didik dalam pembelajaran matematika, pada prasiklus rata-rata sebesar 73 dan siklus I ratarata sebesar 76 serta siklus II rata-rata sebesar 80. Dari data ini, tampak jelas bahwa terjadi kenaikan rata-rata nilai dari prasiklus ke siklus I sebesar 3 digit (4,1\%), dari siklus I ke siklus II terjadi kenaikan sebesar 4 digit (5,3\%), dari prasiklus ke siklus II terjadi kenaikan sebesar 7 digit (9,6\%). Nilai tertinggi motivasi pada prasiklus sebesar 81 siklus I sebesar 85 dan siklus III sebesar 89. Terjadi kenaikan nilai tertinggi dari prasiklus ke siklus I sebesar 4 digit (4,9\%), dari siklus I ke siklus II terjadi kenaikan sebesar 4 digit (4,7\%), dan dari pasiklus ke siklus II terjadi kenaikan sebesar 8 digit (9,9\%). Data nilai terendah dari prasiklus sebesar 65, siklus I sebesar 69, dan siklus II sebesar 75. Terjadi kenaikan nilai terendah dari prasiklus ke siklus I sebesar 4 digit (6,2\%), dari siklus I ke siklus II terjadi kenaikan sebesar 5 digit (8,7\%), dan dari pasiklus ke siklus II terjadi kenaikan sebesar 9 digit $(15,4 \%)$.

Persentase ketercapaian belajar diperoleh pada prasiklus sebesar $41 \%$ dan pada siklus I sebesar 78\% serta siklus II sebesar $100 \%$. Motivasi dari prasiklus ke siklus I peserta didik terjadi kenaikan ketercapaian kelas sebesar 37\%, dari siklus I ke siklus II terjadi kenaikan sebesar 22\%, dan dari prasiklus ke siklus II terjadi kenaikan sebesar 59\%. Hal ini bermakna bahwa motivasi peserta didik dalam pembelajaran matematika dari prasiklus hingga siklus II terjadi kenaikan yang signifikan. Dengan demikian, dapat ditegaskan bahwa melalui model konsrtruktivisme mengoptimalkan motivasi.

Terbangunnya pelaksanaan penumbuhan budi pekerti (pendidikan karakter) mulai dari prasiklus hingga siklus II dapat tercapai dengan baik dan lancar, terbukti adanya perubahan perilaku baik di dalam kelas maupun diluar kelas, misalnya peserta didik bertemu dengan guru selalu menyapa gurunya, yang sebelumnya sebagian besar masih masa bodoh, disiplin hadir mengikuti pembelajaran, mentaati tata tertib sekolah misalnya berseragam, rapi, dan bersih, dan sebagainya. Diperoleh kemajuan penumbuhan budi pekerti peserta didik dalam pembelajaran matematika, pada prasiklus rata-rata sebesar 74 dan siklus I rata-rata sebesar 78 serta siklus II rata-rata sebesar 81 . Dari data ini, tampak jelas bahwa terjadi kenaikan rata-rata nilai dari prasiklus ke siklus I sebesar 4 digit $(5,4 \%)$, dari siklus I ke siklus II terjadi kenaikan sebesar 3 digit (3,7\%), dari prasiklus ke siklus II terjadi kenaikan sebesar 7 digit $(9,5 \%)$.

Nilai tertinggi penumbuhan budi pekerti (pendidikan karakter) pada prasiklus sebesar 83, siklus I sebesar 86, dan siklus III sebesar 89 Terjadi kenaikan nilai tertinggi dari prasiklus ke siklus I sebesar 3 digit (3,6\%), dari siklus I ke siklus II terjadi kenaikan sebesar 3 digit 
(3,5\%), dan dari pasiklus ke siklus II terjadi kenaikan sebesar 6 digit (7,2\%). Data nilai terendah dari prasiklus sebesar 64, siklus I sebesar 70, dan siklus II sebesar 74. Terjadi kenaikan nilai terendah dari prasiklus ke siklus I sebesar 6 digit (9,4\%), dari siklus I ke siklus II terjadi kenaikan sebesar 6 digit $(8,6 \%)$, dan dari pasiklus ke siklus II terjadi kenaikan sebesar 12 digit (18,8\%). Persentase ketercapaian belajar diperoleh pada prasiklus sebesar $41 \%$ dan pada siklus I sebesar $78 \%$ serta siklus II sebesar $100 \%$. Penumbuhan budi pekerti dari prasiklus ke siklus I terjadi kenaikan ketercapaian kelas sebesar 37\%, dari siklus I ke siklus II terjadi kenaikan sebesar 22\%, dan dari prasiklus ke siklus II terjadi kenaikan sebesar 59\%. Hal ini bermakna bahwa penumbuhan budi pekerti (pendidikan karakter) peserta didik dalam pembelajaran matematika dari prasiklus hingga siklus II terjadi kenaikan yang signifikan. Dengan demikian, dapat ditegaskan bahwa melalui model konsrtruktivisme dapat mengptimalkan penumbuhan budi pekerti.

Kemajuan prestasi belajar peserta didik dalam pembelajaran matematika, pada prasiklus rata-rata sebesar 72 dan siklus I rata-rata sebesar 76 serta siklus II rata-rata sebesar 82. Dari data ini, tampak jelas bahwa terjadi kenaikan rata-rata nilai dari prasiklus ke siklus I sebesar 4 digit (5,6\%), dari siklus I ke siklus II terjadi kenaikan sebesar 6 digit $(7,4 \%)$, dari prasiklus ke siklus II terjadi kenaikan sebesar 10 digit (13,9\%). Nilai tertinggi prestasi belajar pada prasiklus sebesar 80, siklus I sebesar 86, dan siklus III sebesar 90. Terjadi kenaikan nilai tertinggi dari prasiklus ke siklus I sebesar 4 digit (7,5\%), dari siklus I ke siklus II terjadi kenaikan sebesar 4 digit (4,4\%), dan dari pasiklus ke siklus II terjadi kenaikan sebesar 10 digit (12,5\%). Nilai terendah dari prasiklus sebesar 62, siklus I sebesar 68, dan siklus II sebesar 76. Terjadi kenaikan nilai terendah dari prasiklus ke siklus I sebesar 6 digit (9,7\%), dari siklus I ke siklus II terjadi kenaikan sebesar 8 digit $(11,8 \%)$, dan dari pasiklus ke siklus II terjadi kenaikan sebesar 14 digit $(22,6 \%)$.

Persentase ketercapaian belajar diperoleh pada prasiklus sebesar $60 \%$ dan pada siklus I sebesar 78\% serta siklus II sebesar 100\%. Prestasi belajar peserta didik dari prasiklus ke siklus I terjadi kenaikan ketercapaian kelas sebesar 1\%, dari siklus I ke siklus II terjadi kenaikan sebesar 22\%, dan dari prasiklus ke siklus II terjadi kenaikan sebesar 40\%. Hal ini bermakna bahwa prestasi belajar peserta didik dalam pembelajaran matematika dari prasiklus hingga siklus II terjadi kenaikan yang signifikan. Dengan demikian, ditegaskan bahwa melalui model konsrtruktivisme mampu mengoptimalkan prestasi belajar materi himpunan

Dalam proses pembelajaran konstruktivisme menurut Vygotsky (dalam Yanto, 2009:1) juga memperkenalkan istilah potensi dalam perkembangan kognitif yang disebut dengan Zone of Proximal Development (ZPD) di mana Zone of Proximal Development, yang diteruskan dengan konsep Scaffolding yang bertujuan untuk membantu anak didik menyelesaiakan tugas yang sukar melalui setrategi interaksi sosial yaitu dengan bantuan dan bimbingan orangorang yang lebih mampu dan lebih mahir dalam membimbing.

Konstruktivisme adalah teori perkembangan kognitif yang menekankan pada peran aktif peserta didik dalam membangun pemahaman mereka sendiri tentang pengetahuan yang dipelajarinya. Slavin (1994:225) mengungkapkan bahwa konstruktivisme dalam sejarah pendidikan lahir dari gagasan-gagasan Piaget dan Vigotsky. Keduanya menekankan bahwa perkembangan kognitif hanya terjadi jika konsepsi-konsepsi yang telah dipahami sebelumnya diolah melalui suatu proses ketidakseimbangan dalam upaya memahami informasi baru. 
Menurut Anderson (dalam Slavin, 1994:48) dalam pandangan konstruktivisme individu dipandang mengkonstruksi pengetahuan secara berkesinambungan mengasimilasi dan mengakomodasi informasi baru. Berarti bahwa pengetahuan merupakan kostruksi atau bangunan manusia sehingga dapat dikatakan bahwa seseorang yang mempelajari suatu pengetahuan berarti belajar mengkonstruksi pengetahuan, atau belajar adalah suatu proses aktif seseorang mengkonsumsi pengetahuan .

Dari hasil penelitian dan pembahasan tersebut di atas, maka dapat ditegaskan bahwa melalui model konsrtruktivisme dapat mengoptimalkan motivasi, penumbuhan budi pekerti (pendidikan karakter), dan prestasi belajar matematika materi himpunan, karena peserta didik mampu membangun pengetahuannya sendiri, meskipun tidak terlepas dari bimbingan guru.

\section{PENUTUP}

secara keseluruhan Hasil penelitian dan pembahasan tentang "Penumbuhan Budi Pekerti Berbasis Lingkungan melalui Model Konstruktivisme dalam Pembelajaran Matematika", dapat disimpulkan bahwa melalui pendekatan konstruktivisme dalam pembelajaran matematika dapat mengoptimalkan penumbuhan budi pekerti berbasis lingkungan, dengan indikator antara lain terdapat kemajuan penumbuhan budi pekerti peserta didik dalam pembelajaran matematika, pada prasiklus rata-rata sebesar 74 dan siklus I rata-rata sebesar 78 serta siklus II rata-rata sebesar 81 . Nilai tertinggi penumbuhan budi pekerti (pendidikan karakter) pada prasiklus sebesar 83, siklus I sebesar 86, dan siklus III sebesar 89. Nilai terendah dari prasiklus sebesar 64, siklus I sebesar 70, dan siklus II sebesar 74. Persentase ketercapaian belajar diperoleh pada prasiklus sebesar $41 \%$ dan pada siklus I sebesar $78 \%$ serta siklus II sebesar 100\%.

Hasil temuan dan tindakan dapat diimplikasikan bahwa paradigma pembangunan pendidikan dewasa ini telah bergeser dari pola teachęr centered ke student centered learning, dari orientasi filosofis yang lebih menekankan dimensi obyektivis-positivis ke subyektivis-interpretatif., guru memiliki kompetensi untuk penumbuhan budi pekerti, memotivasi belajar, membangun mutu, dan meningkatkan prestasi belajar melalui model pembelajaran yang efektif, salah satu di antaranya konstruktivisme yang yang dapat mengakomodasi dan mengoptimalkan potensi peserta didik. konstruktivismeme menekankan perkembangan konsep dan pengertian yang mendalam.

Selanjutnya, saran peneliti, bagi guru, hendaknya mampu menciptakan lingkungan yang nyaman, menumbuhkan budi pekerti, membangun motivasi, dan prestasi belajar peserta didik melalui inovasi pembelajaran, salah satunya konstruktivisme yang mengantarkan peserta didik membangun pengetahuannya sendiri secara maksimal, meskipun masih memerlukan bimbingan guru.. Bagi peserta didik, hendaknya selalu mempersiapkan diri dengan bekal moral (budi pekerti), motivasi, dan berkarakter yang baik, belajar mandiri dan kelompok, peduli lingkungan, disiplin, tanggung jawab, cinta damai, menjalin komunikasi/ bersahabat yang baik, perlu banyak membaca dan berlatih mengerjakan soal-soal secara rutin dan berkelanjutan, aktif memperhatikan penjelasan guru, kreatif dalam menyampaikan ideide kepada guru, mencatat hal-hal yang perlu ditanyakan pada guru, berdiskusi dengan teman sekelas, dan sebainya, yang diharapkan dapat meningkatkan pemahaman konsep dan penguasaan materi ajar. 


\section{DAFTAR PUSTAKA}

Adrian, 2004. "Metode Mengajar Berdasarkan Tipologi Belajar Peserta didik", 20 Oktober 2004. http://www.wordpress.com.

Adnyana, Gede Putra. 2005. Meningkatkan Kualitas Aktivitas Belajar, Keterampilan Berpikir Kritis, Dan Pemahaman Konsep Biologi Siswa Kelas X-5 SMA Negeri 1 Banjar Melalui Penerapan Model Pembelajaran Berbasis Masalah Gulo,W. 2002. Strategi Belajar Mengajar. Jakarta: PT Gramedia Widiasarana Indonesia. http:www. putradnyana-ptk. blogspot.com.

Arvio, Idham. 2012. "Pengertian Prestasi Belajar". http://education-vionet. blogspot.com Astuti, 2012. "Motivasi Berprestasi”. http://stoety.wordpress.com.

Bahar, Haris. 2012. "Motivasi Berprestasi”. http:// harisbahar.blogspot.com .

BSNP. 2007. Standar Kompetensi dan Kompetensi Dasar Untuk SMP/MTs Kurikulum Tingkat Satuan Pendidikan Jenjang Pendidikan Dasar dan Menengah. Jakarta : BSNP.

Darsono, Max, 2000. Belajar dan Pembelajaran. Yoyakarta: IKIP Yogyakarta Press..

Depdiknas. 2003. Standar Kompetensi Mata Pelajaran Biologi Sekolah Menengah Pertama. Jakarta.

Hamalik, Oemar. 2004. Psikologi Belajar dan Mengajar. Bandung : Sinar Baru Algesindo.

Jihad, Asep; Muchlas Rawi; dan Noer Komarudin. 2010. Pendidikan Karakter Teori dan Aplikasinya. Jakarta: Direktorat Manajemen Pendidikan Dasar dan Menengah Kementerian Pendidikan Nasional.

Nasution S., 2002. Kurikulum dan Pengajaran. Jakarta : P.T. C.V. Bina Aksara.

Sardiman, 1980. Psikologi Belajar. Yogjakarta : Andi Offdset.

Slavin, R.E. 1994. Educational Psychology: Theory and Practice (4th Edition). Boston: Allyn and Bacon

Setyarini, M. 2007. Pembelajaran Konstruktivisme Melalui Model Cooperative Learning Tipe STAD Untuk Meningkatkan Aktivitas Dan Hasil Belajar Kimia (PTK Di Kelas XI IPA SMAN 5 Bandar Lampung Tahun Pelajaran 2006/2007. http://www.scribd.com/

Sudrajat, Akhmad, 2008: 4. Strategi Pembelajaran. http://akhmadsudrajat. wordpress.com/

Sudrajat, Akhmad, 2011. "Menjadi Guru Berkarakter". http://akhmadsudrajat.Wordpress .com

Surianto. 2009. "Teori-Pembelajaran-Konstruktivisme". http://surianto200477. wordpress. com/

Suwandi, Sarwiji. 2009. Modul Pendidikan dan Latihan Profesi Guru : Penelitian Tindakan Kelas. Surakarta : UNS.

Syarifah, Maimunah Binti Syed Zin. 2011. "Pembelajaran Secara Konstuktivisme". http:// www.moe.gov.my/bpk/bsk/bpanduan/ konstruktivisme.pdf.

Undang-Undang Republik Indonesia Nomor 20 Tahun 2003 Tentang Sistem Pendidikan Nasional.

Yanto. 2009. Model Belajar Konstruktivisme dalam Pembelajaran Pendidikan Agama Islam (PAI) (Perspektif Vygotsky). http:// digilib.sunan-ampel.ac.id.

Yudi, 2011. "Pengertian Makna Pendidikan Karakter". http://yudinet.com 